\title{
Synthesis of Neurosteroids and its Sexual Dimorphism in the Brain of Tilapia Oreochromis mossambicus
}

\author{
Ramachandra Prabhu, N. Saravanan, Rose Mary Gregoria and R. Moses Inbaraj* \\ Endocrinology Unit, Department of Zoology, Madras Christian College, Tambaram, \\ Chennai 600059, Tamil Nadu, India; inbarajmoses2004@yahoo.com
}

\begin{abstract}
Neurosteroids play a vital role in governing the physiology of reproduction next to neuropeptides and neurotransmitters. Gonadal development influences the steroid synthesis in Central Nervous System (CNS) and also the CNS regulates the gonadal steroid production. It is well known that the receptors of estrogen modulate the production of $\mathrm{GnRH}$, and serotonin, dopamine and GABAergic neurons modulate the steroidogenic enzyme. However, the influence of neurosteroids, Estrogen (E2) and Testosterone (T), and its presence and synthetic pathway variations are not studied in detail in Tilapia. Hence, the present study of identifying various steroids present in the total and regions of Tilapia brain resulted in the quantitative difference in E2, T, 11-Ketotestosterone (11-KT), Androstenedione (A), DHEA, and 21-Hydroxyprogesterone (21-P). The reproductively active fishes of female brain shows the high quantity of testosterone when compare with the male brain. It has been derived that the Cyp19 and Cyp17 gene expressions are higher than the Cyp21 by which the pathway of progesteronal derivatives are not documented. The steroidal production in the incubated regions of Tilapia brain highlights the augmented presence of $5 \alpha$-or $3 \alpha$-reductase evidence the elimination pathway. The quantitative expression of mRNA analysis of $3 \alpha-H S D, 3 \beta-H S D, C y p 17$, Cyp19 and Cyp21 substantiate the variation in sex and maturation of gonadal stages. Aromatase indicate the shift in the sex dependent pathway. The sulphated steroids of pregnenalone and DHEA indicate the presence of Hydroxysteroid Sulfotransferase (HST) for purging action. The study suggests that the sexual modulation can be done at CNS through manipulating the steroidal receptors more particularly at thalamus region of brain.
\end{abstract}

Keywords: Neurosteroid Synthesis, Sexual Dimorphism

\section{Introduction}

Brain is a steroidogenic organ that produces steroidogenic enzymes. Neurosteriods occur in the brain might be catalyzed by biotransformation of cholesterol to various steroids ${ }^{1}$. Steroids are playing a major role during the regulation of sexual differentiation of male and female. Despite neurosteroidogenic enzymes play important role in the regulation of brain development and function, the potential link between brain and gonad by the action of steroid hormones during gonadal sex differentiation is still matter of debate in teleosts ${ }^{2}$. Sex differences in the mammalian and avian brain are organised during early developments as a result of a combination of hormonal and genetic events ${ }^{3}$. This is an irreversible process, and thus the sex of the brain is permanently fixed. In contrast, the phenotypic sex of teleosts, including sex-specific reproductive behaviour, can be manipulated by treatment with exogenous steroid hormones, even after reaching sexual maturity ${ }^{4}$. Several enzymes play an important role in the pathway of steroidogenesis. The mechanism of brain sex differentiation and/or brain activation during early development of teleosts fish is not fully understood yet. Moreover, there is a lack of information regarding the expression of several steroidogenic

*Author for correspondence 
enzymes cyp17, cyp19, cyp21 and 3 3 -HSD in the early brain development and their potential link with gonadal sex differentiation. Therefore, the present study focuses on the analysis of various steroids, Estrogen (E2) and Testosterone (T), 11-Ketotestosterone (11-KT), Androstenedione (A), DHEA and 21-Hydroxyprotgesterone (21-P) present in the regions of the brain of Tilapia, and the expression of steroidogenic enzymes $3 \beta$-HSD, cyp 17 , cyp 19 , cyp 21 and $3 \alpha-$ HSD that are involved in the steroidogenesis in the brain of Tilapia.

\section{Materials and Methods}

\subsection{Sample Collection}

Fish samples of Tilapia were collected from the Lake Nathappetai located at Kanchipuram. Fishes were caught in live condition and they were dissected to collect brain samples. The brain tissues were fixed in a sterilized vials containing with RNAlater and without RNAlater and they were stored at $4^{\circ} \mathrm{C}$ until analysis.

\subsection{Steroid Extraction}

Total brain and the regions of brain (Olfactory and telencephalon (R1); optic (R2); diencephalon with pituitary (R3); cerebellum (R4); and rhombencephalon (R5) were extracted thrice with cyclohexane and ethylacetate (1:1), the solvent evaporated to get steroids of brain.

\subsection{High-performance Liquid Chromatography}

Acetonitrile and water (40:60) were used as the solvent with a flow through rate $1 \mathrm{ml} / \mathrm{min}$., C18 column (ODS $0.2 \mu$ ) used for separation. The UV-visual detector used to identify the steroids at $254 \mathrm{~nm}$ along with photodiode Array (PDA) detector. Estradiol-17 $\beta$ (E2), Testosterone (T), 11-Ketotesto-sterone (11-KT); Androstenedione (A), Dehydroepiandrosterone (DHEA), Progesterone (P), $17 \alpha$-hydroxyprogesterone (17 $\alpha-\mathrm{P}), 20 \beta$-hydroxyprogesterone

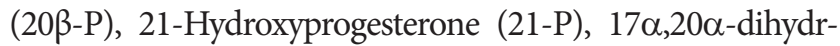
oxyprogesterone $(17 \alpha, 20 \alpha-\mathrm{P}), \quad 17 \alpha, 20 \beta$-dihydroxyprogesterone (17 $\alpha, 20 \beta-\mathrm{P})$, and $17 \alpha, 20 \beta, 21$-trihydroxyprogesterone (21S-P) were used as reference against the brain samples.

\subsection{Synthesis of First Strand cDNA}

Total RNA was isolated with TriReagent (Sigma) from the brain of $O$. mossambicus. The separated RNA has been reverse transcribed into cDNA using RT-PCR method (Medox Kit) using M-MuLV reverse transcriptase. The following primers were used at different reactions.

\section{3 $\beta$-HSD: sense (FP)-CTCTGCAGGAACATCCCAAT, antisense(RP)-TGATCCACAGCATCCACACT, \\ Cyp17: FP-CCAGAGAGGTTCTCCTGCTG, RP-TGGACAACAGCTCCTCACAG, \\ 3 $\alpha$-HSD: FP-CTGTGCCTGAGAAGGTTGCT, RP-CATGTGTCACAGATATCCAC, Cyp19: FP-CCGCTCAATGAGCACGATCTGC, RP- AGCCGCGATCACCATCTCCAA.}

The temperature adopted in the amplification is as follows: $3 \beta$-HSD and $3 \alpha-H S D$ - both are $94^{\circ} \mathrm{C}$ for 2 min in 1 cycle, $94^{\circ} \mathrm{C}$ for $1 \mathrm{~min}, 56^{\circ} \mathrm{C}$ for $1 \mathrm{~min}$ and $72^{\circ} \mathrm{C}$ for $1 \mathrm{~min}$ in 35 cycles; cyp 17 and cyp19- both are $95^{\circ} \mathrm{C}$ for $2 \mathrm{~min}$ in $1 \mathrm{cycle}, 95^{\circ} \mathrm{C}$ for $30 \mathrm{sec}, 48^{\circ} \mathrm{C}$ for $30 \mathrm{sec}$ and $72^{\circ} \mathrm{C}$ for $1 \mathrm{~min}$ in 35 cycles. The PCR products along with $100 \mathrm{bp}$ DNA Ladder were then subjected to $1.2 \%$ Agarose Gel Electrophoresis. After running the gel, the image of specific bands were captured by using UV transillumination under the JH Bio geldoc system.

\section{Results}

Tilapia O. mossambicus brain steroids were measured by HPLC and the results are represented in Table 1. The Testosterone level is higher in female than male at the maturation period, Progesterone and 20 $\beta$-progesterone also absent in male brain. The PCR product and the 100bp DNA ladder were loaded in separate lanes in the gel to know their base pairs expressions. The genes specific bands were observed and visualized by UV-illuminator gel documentation system. The results confirm the presence and expression of steroidogenic enzymes $3 \beta$-HSD, cyp17, cyp19, cyp21 and $3 \alpha$-HSD in the brain of tilapia and it has been quantified in UV-visual spectrometer (Figure 1).

\section{Discussion}

The brain is considered to be an important steroidogenic tissue in teleosts. Present result confirms the presence and expression of steroidogenic enzyme encoding genes in the brain of tilapia. This is the first demonstration of steroidogenic enzyme gene expression in the brain of this fish. Thus $3 \beta-H S D$ is essential for the biosynthesis of all classes of steroid hormones, mainly progesterones, 
Table 1. Presence of steroid in the O. mossambicus brain

\begin{tabular}{|c|c|c|c|c|c|c|}
\hline Steroids Name & $\begin{array}{c}\text { Male total } \\
\text { brain }\end{array}$ & $\begin{array}{l}\text { Male } \mathrm{R} 1 \\
\text { region }\end{array}$ & $\begin{array}{c}\text { Male R3 } \\
\text { region }\end{array}$ & $\begin{array}{c}\text { Female total } \\
\text { brain }\end{array}$ & $\begin{array}{c}\text { Female } \mathrm{R} 1 \\
\text { region }\end{array}$ & $\begin{array}{c}\text { Female R3 } \\
\text { region }\end{array}$ \\
\hline Estrogen & + & - & - & ++ & - & + \\
\hline Testosterone & + & + & + & ++ & - & + \\
\hline Androstenedione & - & - & - & - & - & - \\
\hline 11-Ketotestosterone & ++ & + & + & ++ & - & + \\
\hline Progesterone & - & - & - & + & - & + \\
\hline 21-Hydroxyprogesterone & + & + & + & + & + & + \\
\hline $20 \beta$-Hydroxyprogesterone & - & - & - & + & - & - \\
\hline $17 \alpha, 20 \alpha$-Dihydroxyprogesterone & - & - & - & - & - & - \\
\hline $17 \alpha, 20 \beta$-Dihydroxyprogesterone & - & - & - & - & - & - \\
\hline 17 $\alpha, 21$-Hydroxyprogesterone & - & - & - & - & - & - \\
\hline $17 \alpha, 20 \beta, 21$-Trihydroxyprogesterone & - & - & - & - & - & - \\
\hline
\end{tabular}

(+)- indicates the presence of the steroids in $>10 \mathrm{ng} / 100 \mathrm{mg}$ of tissue. (++)-indicates the $>50 \mathrm{ng} / 100 \mathrm{mg}$ of tissues. (-)-indicates the absence or non-detectable range of steroids.

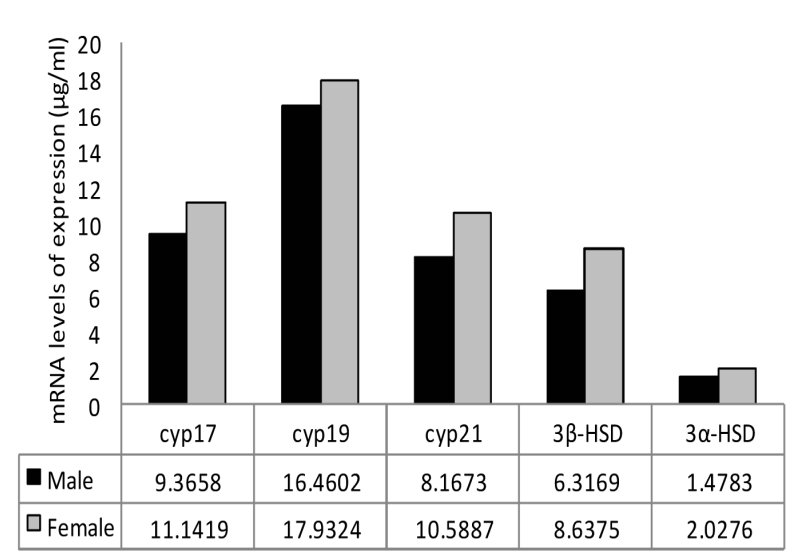

Figure 1. Expression of steroidogenic enzymes encoding genes in the brain of Tilapia.

androgens, estrogens, glucocorticoids and mineralocorticoids. Studies of ${ }^{5}$ showed that rat cerebellar glial and cerebellar granule primary cell cultures expressed $3 \beta$-HSD and P450scc. Rat astrocytes express $3 \beta$-HSD activity ${ }^{6}$ and $\mathrm{P} 450 \mathrm{c} 17$ enzyme expression has been reported in different tissues in vertebrates. P450c17 expression in the CNS and PNS has been proposed first by Compagnone et $\mathrm{al}^{7}$.

Immunohistochemical observations of P450scc, $3 \beta$-HSD, P450c17 and P450aroma have been reported in the Corpus luteum of numerous species, including humans ${ }^{8}$ and bears 9 . Zhou et al. ${ }^{10}$ reported the two P450c17 types encoded by two different genes in fugu, tetraodon, stickleback, tilapia and zebrafish who belong to three different classes in the phylogenetic tree. They further stated that from the sequences and structure of the medaka P450c17 type I and type II genes, the two are completely different ${ }^{10,11}$. In fact, the sex steroid enzyme, cyp19a1 (gonadal aromatase) is a key gene for ovarian differentiation ${ }^{12}$ which found more in the male than in female at brain.

$3 \alpha-\mathrm{HSD}$, the enzyme involved in the conversion of $5 \alpha$-diOHprog into $3 \alpha, 5 \alpha$-triOHprog. Aldo-ketoreductases interconvert weak androgens, estrogens, progestins, mineralocorticoids, and glucocorticoids to their more potent counterparts by catalyzing their reduction and oxidation of keto- and hydroxysteroids, respectively, thereby regulating a wide range of physiological process involved in development, homeostatic and reproduction ${ }^{13}$. Various studies reported the presence of $3 \alpha-H S D$ in the several vertebrates. But till date, no work has been done on this enzyme in tilapia. So, the relationship, similarity among different classes of vertebrates with fishes for $3 \alpha$-HSD has not been known yet. This is the first attempt to report the expression of steroidogenic enzyme of $3 \alpha-H S D$ in the brain tissue of tilapia.

The R1 and R2 regions are showing higher level of steroid compared to other regions of brain, it might be due to the reflection of the pheromonal induction of the opposite sex and it due to be proved by further studies. The steroidal presence further documented by the expression of the gene encoding steroidogenic enzymes studies in the present finding. Cyp19 expression might be higher in male comparing to female, supports the Testosterone abundant in the female brain. Further this study 
highlights difference in male and female by the steroidogenic pathway changes at androstenidione level towards testosterone rather than progestins.

\section{Acknowledgement}

CSIR, UGC and IFCPAR for their project support. Madras Christian College for Institutional support.

\section{References}

1. Corpechot C, Robel P, Axelson M, Sjovall J, Baulieu EE. Characterization and measurement of dehydroepiandrosteronesulfate in rat brain. Proc Natl Acad Sci. 1981; 78:4704-7.

2. Wu GC, Tomy S, Lee MF, Lee YH, Yueh WS, Lin CJ, Lau EL, Chang CF. Sex differentiation and sex change in the protandrous black porgy, Acanthopagruss chlegeli. Gen Comp Endocrinol. 2010; 167:417-21.

3. Arnold AP, Chen X. What does the four core genotypes mouse model tell us about sex differences in the brain and other tissues? Front Neuroendocrinol. 2009; 30:1-9.

4. Munakata A, Kobayashi M. Endocrine control of sexual behavior in teleosts fish. Gen Comp Endocrinol. 2010; 165:456-68.

5. Sanne JL, Krueger K. Expression of cytochrome P450 side chain cleavage enzyme and $3 \beta$-hydroxysteroid dehydrogenase in the rat central nervous system: a study by polymerase chain reaction and in situ hybridization. J Neurochem. 1995; 65:528-36.
6. Akwa Y, Sananes N, Gouezou M, Robel P, Baulieu EE, Le Goascogne C. Astrocytes and neurosteroids: metabolism of pregnenolone and dehydropeiandrosterone regulation by cell density. J Cell Biol. 1993; 121:135-43.

7. Compagnone NA, Bulfone A, Rubenstin JLR, Mellon S. Steroidogenic enzyme P450c17 is expressed in the embryonic central nervous system. Endocrinology. 1995; 136:5212-23.

8. Suzuki T, Sasano H, Tamura M, Aoki H, Fukaya T, Yajima A, Nagura H, Mason I. Temporal and spatial localization of steroidogenic enzymes in premenopausal human ovaries: in situ hybridization and immunohistochemical study. Mol Cell Endocrinol. 1993; 97:135-43.

9. Tsubota T, Taki S, Nakayama K, Mason JI, Kominami S, Harada N, Kita I. Immunolocalization of steroidogenic enzymes in the corpus luteum and placenta of the Japanese black bear, Ursusthibetanus japonicus, during pregnancy. J Reprod.Fertil. 2001; 121:587-94.

10. Zhou LY, Wang DS, Kobayashi T, Yano A, Paul-Prasanth B, Suzuki A, Sakai F, Nagahama Y. A novel type of P450C17 lacking the Lyase activity is responsible for C21- steroid biosynthesis in the fish ovary and head kidney. Endocrinol. 2007; 148:4282-91.

11. Nagahama Y, Yamashita M. Regulation of oocyte maturation in fish. Develop Growth Differ. 2008; 50:S195-S219.

12. Guiguen Y, Fostier A, Piferrer F, Chang CF. Ovarian aromatase and esterogens: A pivotal role for gonadal sex differentiation and sex change in fish. Gen Com Endocrinol. 2010; 165:352-66.

13. Bauman DR, Steckelbroeck S, Penning TM. The roles of aldo-ketoreductases in steroid hormone action. Drug News Perspective. 2004; 17:563-78. 